Pesq. Vet. Bras. 31(5):413-415, maio 2011

\title{
Pulmonary hemorrhage in horses seropositive to leptospirosis ${ }^{1}$
}

\author{
Camila Hamond ${ }^{2}$, Gabriel Martins ${ }^{2}$, Jorge Reis ${ }^{3}$, Elizabeth Kraus ${ }^{3}$, Aline \\ Pinna $^{2}$ and Walter Lilenbaum ${ }^{2^{*}}$
}

\begin{abstract}
Hamond C., Martins G., Reis J., Kraus E., Pinna A. \& Lilenbaum W. 2011. Pulmonary hemorrhage in horses seropositive to leptospirosis. Pesquisa Veterinária Brasileira 31(5):413-415. Departamento de Microbiologia e Parasitologia, Universidade Federal Fluminense, Niterói, RJ 24210-030, Brazil. E-mail: mipwalt@ vm.uff.br

The aim of this study was to verify the occurrence and severity of pulmonary hemorrhage $(\mathrm{PH})$ in horses seropositive or not to leptospirosis. A total of 84 training horses were tested for anti-Leptospira antibodies and submitted to endoscopy of the upper airways 30-60 minutes after exercise. Forty-nine (46.4\%) horses were seropositive (titer $\geq 100$ ) to serovar Copenhageni. Seventeen horses $(20.2 \%)$ presented $\mathrm{PH}$ in different grades, significantly more commonly observed in seropositives (34.7\%) than seronegatives $(8.6 \%)(p<0.05)$, and also more severe in the first. Additionally, a seropositive horse is 4.26 times more likely (OR) to present $\mathrm{PH}$ than a seronegative one. Fifteen days after specific antibiotic treatment for leptospirosis a significant improvement in grade of hemorrhage was observed. Therefore it is suggested that leptospirosis may potentiate the severity of $\mathrm{PH}$ and that specific antibiotic treatment directed towards leptospirosis may help to control the disease.
\end{abstract}

INDEX TERMS: Leptospirosis, horses, pulmonary hemorrhage.

\begin{abstract}
RESUMO.- [Hemorragia pulmonar em cavalos soropositivos para leptospirose.] O objetivo foi estudar a ocorrência e severidade de hemorragia pulmonar (HP) em cavalos soropositivos ou não à leptospirose. Um total de 84 cavalos em treinamento foi testado para anticorpos antiLeptospira e submetidos à endoscopia das vias aéreas superiores de 30-60 minutos após exercício. Quarenta e nove $(46,4 \%)$ animais foram soropositivos (títulos $\geq 100$ ) para o serovar Copenhageni. Dezessete cavalos $(20,2 \%)$ apresentaram HP, significativamente mais observada em soropositivos $(34,7 \%)$ do que em soronegativos $(8,6 \%)$ $(p<0,05)$ e também mais grave nos primeiros. Adicionalmente, um cavalo soropositivo tem 4,26 mais chances (OR) de apresentar PH do que um soronegativo. Quinze dias após o tratamento com antibiótico específico para leptospirose uma melhoria significativa no grau de hemorragia foi observada. Portanto, sugere-se que a leptospirose pode
\end{abstract}

\footnotetext{
${ }^{1}$ Received on October 26, 2010.

Accepted for publication on December 15, 2010.

2 Departamento de Microbiologia e Parasitologia, Instituto Biomédico, Universidade Federal Fluminense (UFF), Rua Hernani Mello 101, sala 309, Niterói, RJ 24210-030, Brazil. *Corresponding author: mipwalt@vm.uff.br

${ }^{3}$ Médico Veterinário autônomo, Jockey Club Brasileiro, Rua Mario Ribeiro, Rio de Janeiro, RJ 22430-160, Brazil.
}

potencializar a severidade da HP e que o tratamento com antibióticos específicos recomendados para leptospirose pode ajudar a controlá-la.

TERMOS DE INDEXAÇÃO: Leptospirose, cavalos, hemorragia pulmonar.

\section{INTRODUCTION}

Leptospirosis is a widespread zoonotic disease caused by infection with spirochetes belonging to the genus Leptospira (Faine et al. 2000). It is largely reported in tropical countries (Langoni et al. 2004). Titers to several serovars have been reported in horses and, in general, serovars from the Icterohaemorrhagiae serogroup (as Copenhageni), besides Bratislava and Pomona, tend to be most prevalent (Langoni et al. 2004). Leptospirosis in horses is frequently sub-clinical, the clinical cases being associated with abortion and recurrent uveitis, although sporadic cases of systemic disease have also been reported (Van den Ingh et al. 1989).

Although hemorrhagic leptospirosis has been reported as the cause of death of 12 foals (Van den Ingh et al. 1989), pulmonary aspects of the disease are poorly studied in horses. However, there have been widely reported in humans, and pulmonary involvement in leptospirosis varies from $20 \%$ to $70 \%$, with hemoptysis in $3-25 \%$ of patients and chest pain in 10\% (Pereira da Silva et al. 2002). In human beings, 
vascular injury and areas of focal hemorrhage are prominent features. Intra-alveolar hemorrhage is detected in the majority of patients, and may be severe enough to cause death (Levett 2001).

Therefore, considering the widespread occurrence of horse leptospirosis in tropical countries as Brazil and the well known involvement of this infectious disease on pulmonary injuries in humans, we hypothise that seropositivity to leptospirosis may be related to the occurrence and severity of pulmonary hemorrhage in horses.

\section{MATERIALS AND METHODS}

A total of 84 racing Thoroughbred horses (2-5 years) of 35 colt, 27 fillies and 22 gelding were studied, situated at Jockey Club Brasileiro in Rio de Janeiro, Brazil. The animals were not vaccinated for leptospirosis.

Total blood was collected in Vacutainer ${ }^{\circledR}$ tubes from vena jugularis. Sera were harvested following centrifugation of clotted blood and were stored at $-20^{\circ} \mathrm{C}$ to be tested as a batch. For detection of anti-Leptospira antibodies, the microscopic agglutination test (MAT) was performed (Faine et al. 2000). The antigens were a panel of 24 strains (representing all described serogroups) of live Leptospira grown in liquid medium EMJH (Difco, Detroit,MI, USA), and free of contamination or self-agglutination. The highest titer reached was used to identify the infective serovar. Animals were considered positive when presented titers $\geq 100$.

Endoscopic examinations were performed 30-60 minutes after racing (light: two minutes canter - and intense: three minutes running 8 meters/second exercise) and using flexible fibroscolonoscopy (Olympus, GIF, type CF-P20L) $1.60 \mathrm{~m}$ long with $14 \mathrm{~mm}$ diameter and a halogen light $15 \mathrm{v} / 150 \mathrm{~W}$. Sedatives were not used in this test. Severity of $\mathrm{PH}$ was measured according to described in the literature (Hinchicliff et al. 2005).

For all seropositive animals a specific treatment based on the application of procaine penicillin $\mathrm{G}$ with streptomycin (Pen \& Strep®, Lavizoo, Campinas, SP, Brazil), 25mg/kg (Faine et

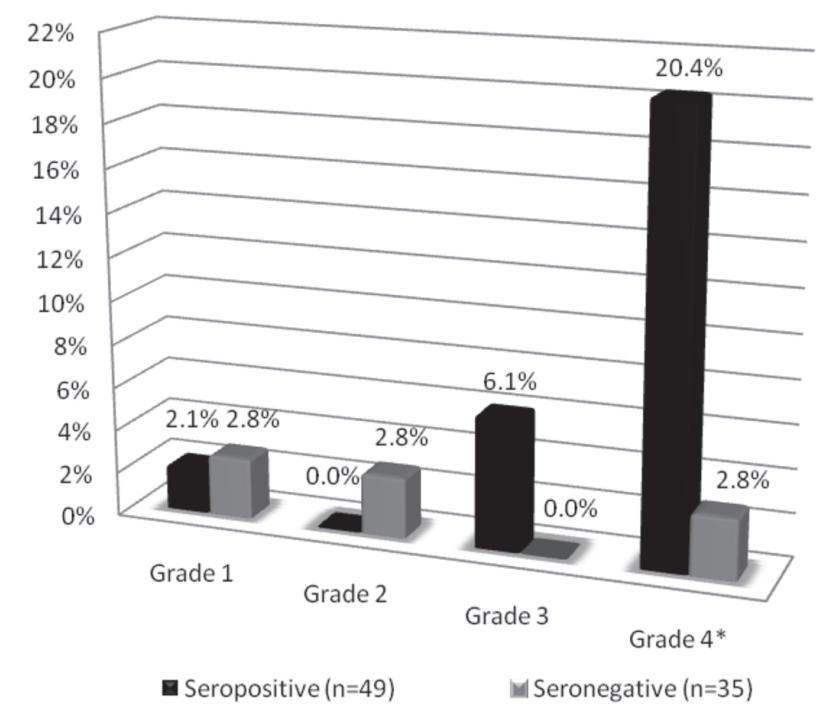

Fig.1. Classification of severity (grades) of pulmonary hemorrhage observed in horses seropositive to Copenhageni and seronegatives to leptospirosis in Rio de Janeiro, Brazil.

* Significant differences between groups $(p<0.01)$. al. 2000) was proposed. Since procaine may be interpreted as dopping in racing horses, some owners did not authorize it's use, and only 18 out of the 49 horses seropositive to Copenhageni $(36.7 \%)$ were treated.

The results were analyzed by the chi-square test $\left(c^{2}\right)$. Severity of $\mathrm{PH}$ at different moments of the study was compared by the Fischer exact test. Data analysis was based on SPSS statistical software (SPSS Inc., Chicago, USA), and results were considered as significant when $p<0.05$. Odds Ratio $(O R)$ was calculated considering a confidence interval of $95 \%$.

\section{RESULTS}

From the 84 serum samples tested, 49 (58.3\%) were reactive, all of them to serovar Copenhageni. Ten (20.5\%) presented titer of 100 , eight (16.4\%) presented titer of $200,17(34.5 \%)$ titer 400 and $14(28.6 \%)$ presented high titers $(\geq 800)$.

Seventeen horses $(20.2 \%)$ presented $\mathrm{PH}$, more frequently in seropositives (34.7\%) than in seronegatives (8.6\%) $(p<0.005)$. Additionally, a seropositive horse is 4.26 times more likely (OR, $\mathrm{Cl} 95 \%$ ) to present $\mathrm{PH}$ than a seronegative one. From those, seven presented $\mathrm{PH}$ even after light exercise (Grade 4 with the presence of epistaxis), while ten only presented hemorrhagic symptoms after intense exercise. Regarding the severity of $\mathrm{PH}$, two horses presented a mild form (Fig.1), one with Grade 2, three with Grade 3 and eleven presented a severe form of $\mathrm{PH}$ (Grade 4). Noteworthy observe that $\mathrm{PH}$ was more severe $(\mathrm{p}<0.01)$ in seropositives than in seronegatives (Fig.1).

All the seven horses seropositive to Copenhageni that presented $\mathrm{PH}$ even after light exercise that were treated. None of those animals became free of $\mathrm{PH}$, but a significant reduction on its severity could be observed. Fifteen days after the treatment (d15) two animals (28.6\%) had decreased severity from Grade 4 to 3, while five (71.4\%) decreased to Grade 2.

\section{DISCUSSION}

In this study, we verified the presence of anti-Leptospira agglutinins in sera from 49 horses, all of them to Copenhage$\mathrm{ni}$, a member of Icterohaemorrhagiae serogroup, which is maintained by rats (Faine et al. 2000, Levett 2001). Although no attempt was made to isolate leptospirosis or evidence it's DNA, we assume that the horses were infected, considering both serology and local epidemiology, since MAT is the reference test by WHO. Additionally, rats have been detected near the supply warehouse and villages of Jockey Club, which are located on a flat area and are subject to occasional flooding. Finally, results of serology agree with several other studies performed in horses in Brazil that indicate members of Icterohaemorrhagiae serogroup as predominant serovars in horses maintained in urban regions (Langoni et al. 2004).

Noteworthy observe that Copenhageni is also the predominant serovar in humans in Rio de Janeiro (Pereira et al. 2000) and has been isolated from human cases with severe pulmonary form of leptospirosis (Pereira da Silva et al. 2002). Pulmonary alterations due to leptospirosis determined by Copenhageni have also been demonstrated in other species, 
as marmoset monkeys (Callithrix jacchus) (Pereira et al. 2005) and guinea pigs (Nally et al. 2004). Those data reinforce the hypothesis of a similar physiopathogeny of pulmonary lesions in horses infected by the same serovar.

There is a well described syndrome in racing horses known as Exercise-induced pulmonary hemorrhage (EIPH). Its diagnosis requires, besides endoscopy, the examination of bronchoalveolar lavage fluid (BAL) or tracheal aspirates. In this study, we cannot refer to EIPH, and not only because of the lack of that analysis. More importantly, seven out of the 17 horses that presented $\mathrm{PH}(41.2 \%)$ did it even after a light movement. Therefore, we believe that this hemorrhage cannot be referred as "induced by exercise".

There are speculations about the etiological factors of $\mathrm{PH}$ in the athletic horses, and a variety of factors have been suggested as causes or influencers, including exercises. From the group of seropositives, 14 (35.9\%) presented EIPH, versus three $(6.7 \%)$ seronegatives, a significant difference. An important and significant difference on the severity of $\mathrm{PH}$ was also observed according to the seroreactivity to leptospirosis. Not only seropositives have higher grades of $\mathrm{PH}$, but a good therapeutic response was observed after specific antibiotic therapy for leptospirosis. After 15 days of the treatment, without any other treatments, all the treated horses demonstrated an important reduction of severity of $\mathrm{PH}$, from grade 4 to 3 (two animals) or 2 (five animals).

Leptospirosis leads to a vascular capillary damage and fragility, vasculitis and subsequent bleeding into the tissues (Levett 2001), what may lead to $\mathrm{PH}$, more evidently after exercise. The high pulmonary vascular pressure observed during intense physical exercise, combined with the increased inspiratory effort could result in the failure stress of pulmonary capillaries leading to $\mathrm{PH}$ (Manohar et al.1999). Thus, it is suggested that the severity of $\mathrm{PH}$ in racing horses may be influenced by leptospirosis determined by serovar Copenhageni.

\section{CONCLUSION}

Considering the results of the present study, we conclude that leptospirosis determined by serovar Copenhageni can be related to pulmonary hemorrhage in horses, mainly under tropical conditions.

Acknowledgements.- To Prof. D.B. Lessa (UFF, Brazil) and Dr. R. Ferreira (Dept Agriculture, Brazil) for their suggestions. This study was supported by CNPq and FAPERJ, Brazil.

\section{REFERENCES}

Faine S., Adler B., Bolin C. \& Perolat P. 2000. Leptospira and Leptospirosis. $2^{\text {nd }}$ ed. MedSci, Melbourne. 272p.

Hinchcliff K.W., Jackson M.A., Brown J.A., Dregde A.F., O'Callaghan P.A., McCaffrey J.P., Morley P.S., Slocombe R.F. \& Clarke A.F. 2005. Tracheobronchoscopic assessment of exercise-induced pulmonary hemorrhage in Thoroughbred race horses. J. Am. Vet. Med. Assoc. 6:596-598.

Langoni H., Da Silva A.V., Pezerico S.B \& De Lima V.Y. 2004. Antileptospira agglutinins in equine sera, from São Paulo, Goias, and Mato Grosso do Sul, Brazil, 1996-2001. J. Venom. Anim. Toxins incl. Trop. Dis. 3:207-218.

Levett P.N. 2001. Leptospirosis. Clin. Microbiol. Rev. 14:296-326.

Manohar M. \& Goetz T.E. 1999. Pulmonary vascular pressures of strenuously exercising Thoroughbreds during intravenous infusion of nitroglycerin. Am. J. Vet. Res. 60:1436-1440.

Nally J.E., Chantranuwat C., Wu X.Y., Fishbein M.C., Pereira M.M., Da Silva J.J., Blanco D.R. \& Lovett M.A. 2004. Alveolar septal deposition of immunoglobulin and complement parallels pulmonary hemorrhage in a guinea pig model of severe pulmonary leptospirosis. Am. J. Pathol. 164:1115-1127.

Pereira da Silva J.J., Dalston M.O., De Carvalho J.E.M., Setúbal S., De Oliveira J.M.C. \& Pereira M.M. 2002. Clinicopathological and immunohistochemical features of the severe pulmonary form of leptospirosis. Revta Soc. Bras. Med. Tropl 35:395-399.

Pereira M.M., Matsuo M.G., Bauab A.R., Vasconcelos S.A., Moraes Z.M., Baranton G. \& Saint Girons I. 2000. A clonal subpopulation of Leptospira interrogans sensu stricto is the major cause of leptospirosis outbreaks in Brazil. J. Clin. Microbiol. 38:450-452.

Pereira M.M., Da Silva J.J., Pinto M.A., Da Silva M.F., Machado M.P., Lenzi H.L \& Marchevsky R.S. 2005. Experimental leptospirosis in marmoset monkeys (Callithrix jacchus): A new model for studies of severe pulmonary leptospirosis. Am. J. Trop. Med. Hyg. 72: 1320.

Van den Ingh T.S., Hartman E.G. \& Bercovich Z. 1989. Clinical Leptospira interrogans serogroup Australis serovar lora infection in a stud farm in The Netherlands. Vet. Quart. 11:175. 